\title{
Brown Invisible in France? The French Perception and Reception of Eighteenth-Century British Gardens
}

\author{
Laurent Châtel and Monique Mosser
}

The overall question of Lancelot Brown's reputation in France is vexed, as one is hard pressed to find evidence of his having a high profile, or any profile at all, in eighteenth-century and early nineteenth-century French writings. Is it possible that the 'famous Mr Brown' was not so famous in France after all? Admittedly, France experienced several waves of anglomania throughout the eighteenth century, with prominent peaks in the 1750 s and in the 1770s. The furore, or furor hortensis, as some have called it, embraced a rage for all things English in the garden. ${ }^{1}$ After his stay in England, Voltaire was very much taken with native creativity and it was nourished by his special relationship with William Chambers, as can be ascertained from their exchanges in 1772: 'Sir, it is not enough to love, or have gardens; one must have eyes to see them, and legs to walk in them.' Although not French, Jean-Jacques Rousseau contributed to shaping French mentalités: he spent some time between 1765 and 1767 at Wootton Hall (Staffs) and was no less enthusiastic in 1772 when he thanked the Duchess of Portland for sending him a copy of William Mason's English Garden: 'the book on English gardens you have been so kind as to send me ... I do not underestimate its value, since it is esteemed and translated in this country; and besides I am bound to like the subject, having been the first on the Continent to celebrate and transmit these very gardens. ${ }^{3}$ Voltaire and Rousseau disputed their claims to be the first spokesmen in French of the so-called English garden, but in fact interest had been widespread through private epistolary networks. Equally, it is worth noting that the circulation of drawings also insured a continuous knowledge of English innovations as evidenced by several instances of artists, landowners, and exiled aristocrats producing visual

\footnotetext{
1 'The furor hortensis has seized me, and my acre of ground here affords me more pleasure than kingdoms do to Kings' in Lord Mahon (Ed.), The letters of the Earl of Chesterfield (London: Richard Bentley, 1845), 'To the Bishop of Waterford, 1751', Vol. 3, p. 429.

2 Letter to William Chambers from Ferney, 1 August 1772 in Voltaire, François-Marie Arouet, CEuvres complètes (1877-85), Vol. 48, p. 143: 'Monsieur, ce n'est pas assez d'aimer les jardins, ni d'en avoir; il faut avoir des yeux pour les regarder, et des jambes pour s'y promener'.

3 J. J. Rousseau, Oeuvres complètes, 'Letters to the Duchess of Portland', letter n IX: 'le livre des jardins anglais que vous avez bien voulu penser à m'envoyer? Quoique son plus grand prix fût venu pour moi de la main dont je l'aurais reçu, je n'ignore pas celui qu'il a par lui-même, puisqu'il est estimé et traduit dans ce pays; et d'ailleurs j'en dois aimer le sujet, ayant été le premier en terre-ferme à célébrer et faire connaître ces mêmes jardins'. See Cook, A. (2007). Botanical exchanges: Jean-Jacques Rousseau and the Duchess of Portland. History of European Ideas, 33(2), 142-156.
}

How to cite this book chapter:

Châtel, L. and Mosser, M. 2020. Brown Invisible in France? The French Perception and Reception of Eighteenth-Century British Gardens. In Finch, J. and Woudstra, J. (Eds.), Capability Brown, Royal Gardener: The business of place-making in Northern Europe, pp. 181-198. York: White Rose University Press. DOI: https://doi.org/10.22599/CapabilityBrown.m. CC BY-NC 4.0 

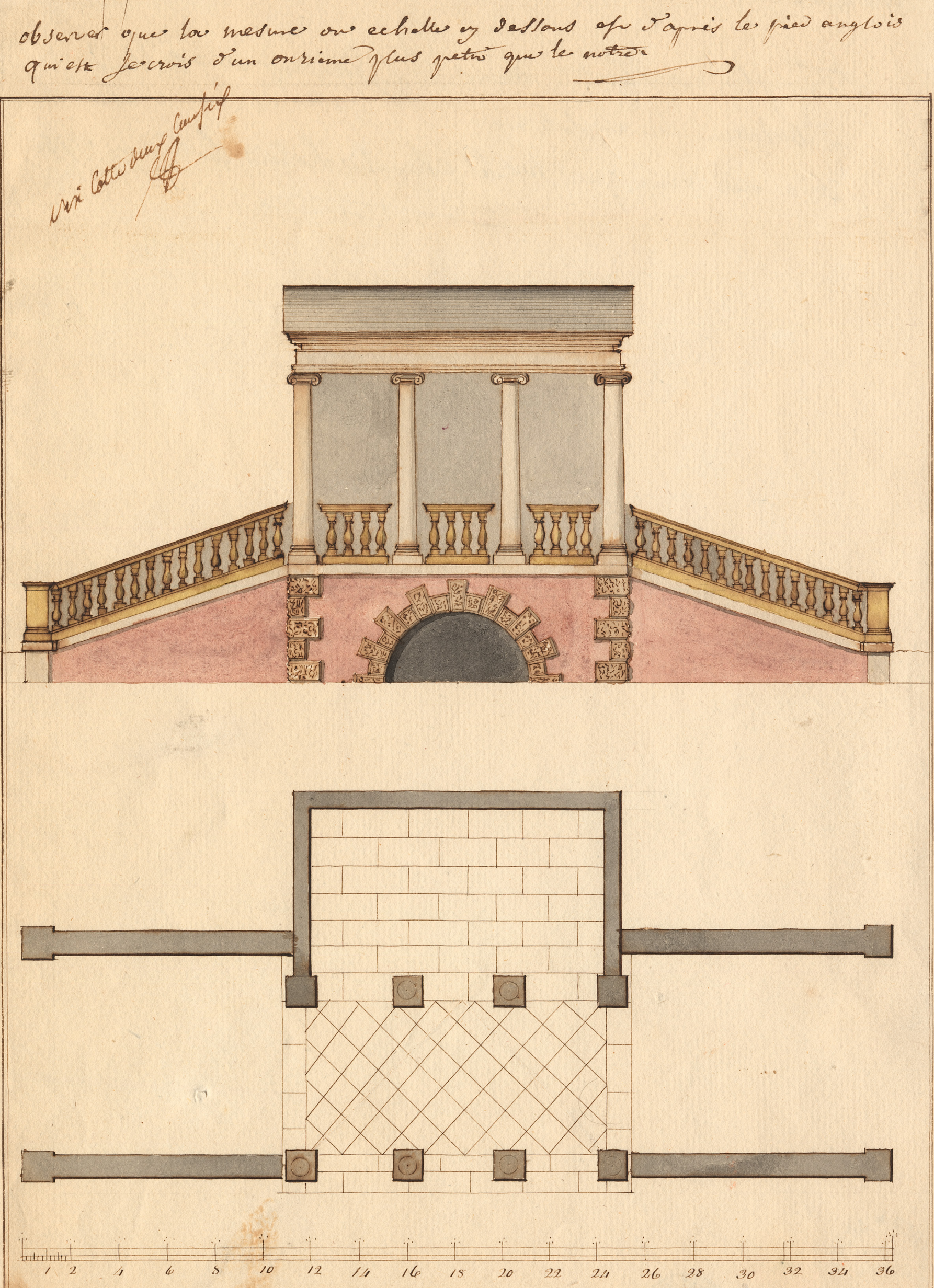


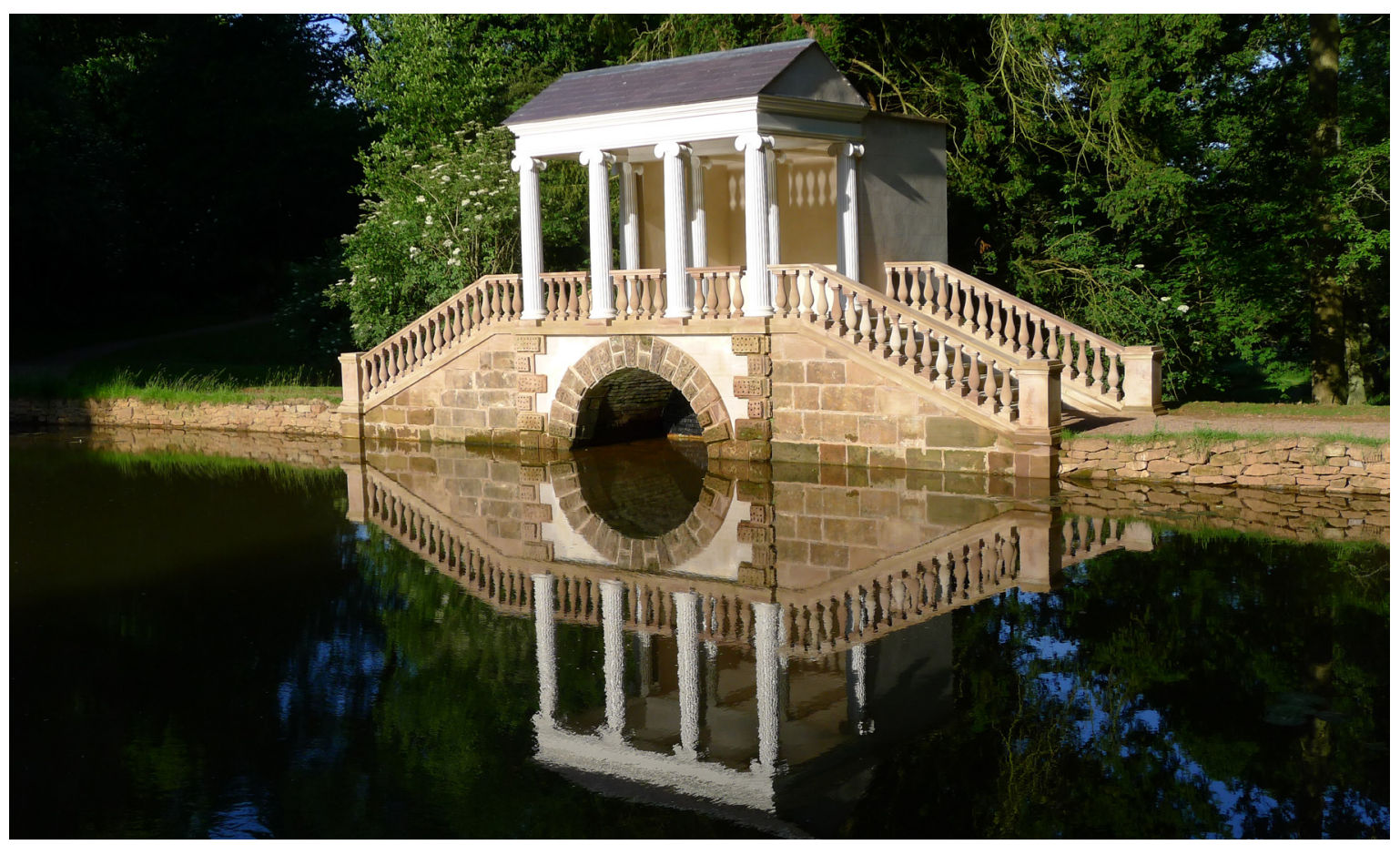

Figure 13.2: The restored Hagley Bridge today, at Hagley Hall. Photo copyright Laurent Châtel, CC BY-NC 4.0.

records: Pierre-Jacques Fougeroux's drawing trip recording the English gardens in the 1720s; ${ }^{4}$ the Marquis de Marigny's exchanges with Lord Lyttleton (c. 1770s) about the Hagley Bridge, as attested by the drawing sent out to Marigny, on which today's restoration is based (Figures 13.1 and 13.2); ${ }^{5}$ François-Joseph Bélanger's own series of drawings; ${ }^{6}$ and finally Lancelot Turpin de Crissés drawings of the 1790 s. $^{7}$ The fact that English hortulan ideas were well established in France by the 1770s comes out clearly in the following extract from Grimm and Diderot's Correspondance Littéraire in 1771:

The French garden and the English garden are formed on two distinct principles. They each have a beauty of their own. When we have done with our petty national arrogance, which only befits children, we will agree that in order to make music one must learn from the Italians and the Germans, and to make gardens one must turn to the English; we will realize that it is not up to one single person to come up with the truth, the good, and the beautiful, as if by some exclusive prerogative, and that one is less of a fool for giving up one's pretentions swiftly. ${ }^{8}$

However, while there is ample evidence of Franco-British cultural exchanges, it is much more difficult to assess which specific British designers had any influence in the making of French gardens (Figure 13.3). The

\footnotetext{
${ }^{4}$ Jacques, D. \& Rock, T. (2006). Pierre-Jacques Fougeroux: A Frenchman's commentary on English gardens of the 1720s. In M. Calder (Ed.), Experiencing the Garden in the Eighteenth Century (pp. 214-235). Berne: Peter Lang.

${ }^{5}$ Mosser, M. (1973). Monsieur de Marigny et les jardins: Projets inédits de fabriques pour Menars. Bulletin de la Société de l'Histoire de l'Art Français 1972, 270-293.

${ }^{6}$ Barrier, J. (1997). Bélanger et l'Angleterre. In M. Constans (Ed.), Bagatelle dans ses jardins (pp. 167-177). Paris: Action Artistique de la Ville de Paris.

7 Clark, J. (2013). An amateur artist's sketching tour of late eighteenth-century English gardens. Garden History, 41(2) $208-223$.

${ }_{8}$ Tourneux, M. (Ed.). (1879). Correspondance, littéraire, philosophique et critique par Grimm, Diderot, Raynal, Meister. Paris: Garnier Frères, see Vol. 9 [probably Diderot] 'Juillet 1771. L'Art de former les jardins, Latapie', p. 348: 'Quand nous serons défaits de la petite morgue nationale qui ne sied bien qu'aux enfants, nous conviendrons qu'il faut apprendre des Italiens et des Allemands à faire de la musique, et des Anglais à former des jardins; nous sentirons qu'il n'est pas donné à un seul peuple de rencontrer toujours le vrai, le bon et le beau, comme par privilège exclusif, et que le moins sot est celui qui renonce le plus vite à ses prétentions'.
}

Figure 13.1 (page 182): Drawing of Hagley Bridge, c. 1770s, contained in a letter from Lord Lyttelton to Marquis de Marigny. Copyright: Fonds de Ménars - Marquis de Marigny, 25 J 2/6 AD41. CC BY-NC-ND 4.0. 


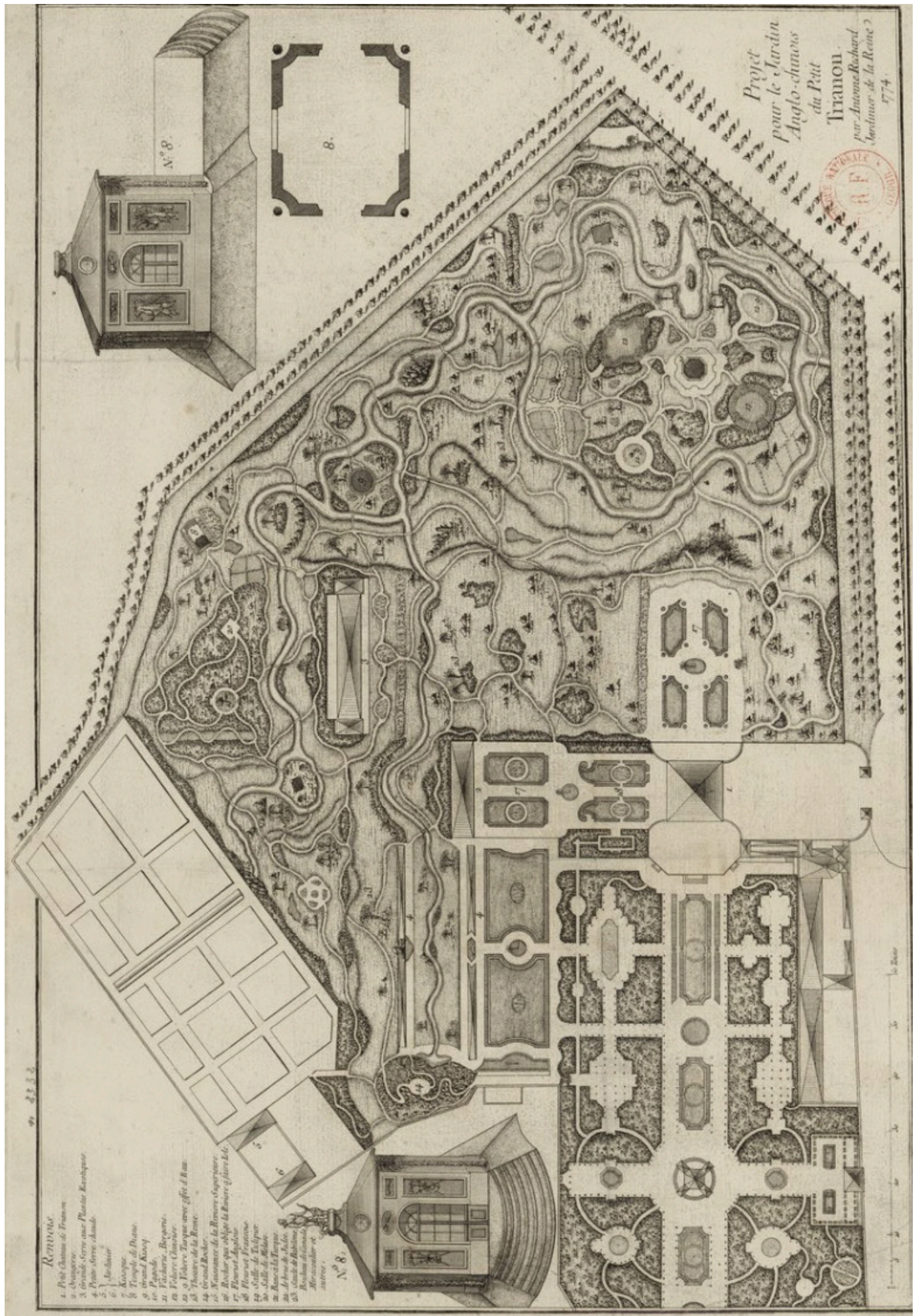

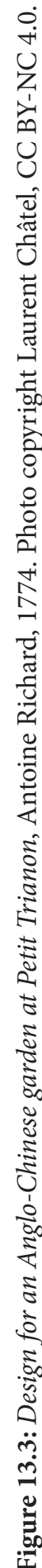


translation of the 'English garden' in France, or across Europe for that matter, boasts a rich historiography, ${ }^{9}$ but previous studies have perhaps too often focused on establishing the very first form as if there were a specific originator or original creation which ignited the rage; John Harris, for instance, contributed to the ongoing debate about the first French jardin anglais. ${ }^{10}$ Recent work on cultural transfers points to a piecemeal, incremental transition from one style or fashion to another, but also to a plural, co-creative, pan-European transfer rather than an actual transplantation of forms from one country to another. Looking at garden history through the lens of reception is thus instructive and rewarding as it provides a corrective to ongoing myths and die-hard misconstructions. It is hoped this sketch of 'Brown in France' will provide food for thought for a more extensive study of reception of forms and people in European garden historiography.

\section{‘Capability’ Brown in France: Reviewing the Facts}

Three points may be made at the outset: firstly, overall occurrences of the name of Brown are few and far between; secondly, there were hardly any references before 1784; thirdly, whenever Brown was referred to in the first French 'garden histories' after 1784, he featured as a marker of evolution, not revolution. He was referred to as 'celebrated' but was not identified as a specific 'stage' or 'period' in garden history - he featured alternately as a continuum following on from Kent, a transition to Repton, or lastly, a corruption of taste in the eyes of the Picturesque authors Richard Payne Knight and Uvedale Price.

\section{The Reception of Brown in Eighteenth-Century France}

The first French reference to Brown is oblique - it does not name Brown but clearly refers to him implicitly. It is found in a French guidebook to Stowe by the unknown 'J. de C., Les charmes de Stow (1748); this guide, partly based on writings by William Gilpin, refers to the latest improvements beyond the Gothick Temple, but declares that nothing may be reported as it is as yet incomplete:

[N]ew improvements. ... As I do not know his design, I would not know what to say about it. ... What may be quite certain, judging by the Taste and Magnificence that have already been displayed, these latest embellishments cannot fail to be of the same stamp. ${ }^{11}$

Brown's name is not mentioned but instead homage is paid to the owner - a phenomenon which may account for Brown's name not necessarily being recorded in travel books and ekphrastic accounts. However, it is worth mentioning that Brown's direct involvement with these particular developments has yet to be ascertained.

One might have considered Thomas Whately to be a conduit for Brown, but he made no mention of him, and as a result the French text produced a year later did not contribute to spreading Brown's style in France. ${ }^{12}$ The French translator François-de-Paule Latapie did not add a footnote or commentary either. However, four years later, Antoine-Nicolas Duchesne (1747-1827), Keeper of the Royal Buildings and botanist, did refer to Brown. The first direct reference to Brown is a small but important one as it sheds light on the elusiveness of French transmission. Indeed, in his book, Sur la formation des jardins par lauteur des considérations sur le jardinage [On the Formation of Gardens] of 1775, Duchesne wrote that Whately was the 'first to write about the art of forming gardens, according to Kent \& Brown, just as Leblond and Dargenville had put forward the principles

\footnotetext{
${ }^{9}$ See Wiebenson, D. (1978). The picturesque garden in France. Princeton: Princeton University Press; Hunt, J. D. (2002). The picturesque garden in Europe. London: Thames and Hudson; and Mosser, M. (2011). Rapporter le tableau sur le terrain: fabrique et poétique du jardin pittoresque. In C. de Bourgoing (Ed.), Le Jardin romantique en France (pp. 32-42). Paris: Musée de la vie romantique.

${ }^{10}$ Harris, J. (2001). L'Idole du Temple: The first French gardener in the Brownian style. Garden History, 29(1), 'Lancelot Brown (1716-83) and the landscape park', 36-47.

11 de C., J. (1748). Les charmes de Stow. London: 'de nouveaux ornements \& auxquels il fait travailler à force. Comme je ne sais point son Plan, je ne saurois rien vous dire là dessus. Ce qu'il y a de bien certain, c'est qu'à en juger par les preuves qu'il a déjà données de son Goût \& de sa Magnificence, ces nouveaux embellissements ne peuvent manquer d'être marqués au même coin'.

12 Whately, T. (1771). L'Art de former les jardins modernes. Paris.
} 
of our Le Nostre in $1709 \cdot{ }^{13}$ Such a pithy statement which connects Whately with 'Kent and Brown' is all the more surprising on the part of Duchesne as Whately never in fact referred to Brown. Admittedly, this reference to Brown is made in a footnote, but it reveals that there also was oral transmission: knowledge acquired via books was supplemented and sustained through conversation and discussion. Thus, knowledge acquired in situ, orally, percolated down and was evidently mixed up with reminiscences from readings of Whately. At Versailles, Duchesne had clearly heard of Brown via Richard Mique or the abbé Pierre-Charles Nolin (1717-96), director of the Royal Nurseries since 1765. In the autumn of 1776 Duchesne and Nolin were sent on an official mission for Marie-Antoinette, with a view to observing the extent of English achievements in situ and notably their way of transplanting trees. In all likelihood, Duchesne would have been introduced to Brown at Hampton Court. ${ }^{14}$

The third reference occurs in 1779 and is also an oblique one - it is Carmontelle's definition of Monceau as 'un jardin extraordinaire', which he sets in opposition to a garden striving to be 'an imitation of a Nation which, in making natural gardens, mows every single piece of turf and spoils nature by displaying the affected art of a gardener without imagination. ${ }^{15}$ The one and only reference to Brown in the French translation of Hirschfeld's Theorie der Gartenkunst in 1779: 'Brown and other excellent garden artists continued to follow the path of the new taste'16 - confirmed that Brown 'followed' rather than 'spearheaded' taste, or, as Linda Parshall argued recently, he was 'marginally aware of the recent contributions of Capability Brown. ${ }^{17}$ In 1781, the Prince de Ligne made only a passing remark, all the more enigmatic for its brevity: 'Browne [sic] stood up, produced effects, and put the final touches. ${ }^{18}$ In 1782, Delille made no reference to Brown, but again one may detect an implicit hint and scathing side-remark, as oblique as Carmontelle's, when one reads 'I know that a severe taste has wanted all these Greek and Roman gods from gardens exiled' (Canto IV). In 1784, Brown appeared for all to see in the Duc de Nivernois's translation of Walpole's History of the Modern Taste, but it was a brief encounter for the French reader since Walpole declared that Brown, being a living artist, could not fall within the plan of his book and he added:

and did living artists come within my plan, I should be glad to do justice to Mr. Brown; but he may be a gainer, by being reserved for some abler pen. ${ }^{19}$

It is striking that, after Brown's death in 1784, his name appeared more frequently, possibly owing to the transmission of the news of his death and subsequent obituaries.

Turning to travel diaries is instructive - although one has to bear in mind that they were often unpublished manuscripts, and, however important retrospectively for later biographers, they do not constitute testimonies of a public reception and promotion of Brown at the time. However, travel diaries may be said to give him a much greater profile. François-Armand Frédéric de La Rochefoucauld (1765-1848), in his Mélanges sur l'Angleterre, refers to one 'Le Brun', which most probably is a reference to 'Brown':

13 'Le Traducteur (Latapie) nous instruit que sont Auteur est le premier, qui ait traité par écrit, l'année précédente, l'Art de former les Jardins, suivant la manière de Kent \& de Brown, comme Leblond \& Dargenville avoient en 1709, exposé les principes de notre Le Nostre'. In Duchesne, A.-N. (1775). Sur la formation des jardins par l'auteur des considérations sur le jardinage (p. 86). Paris.

${ }^{14}$ Our thanks go to Gabriela Lamy (Trianon) for sharing her work on Duchesne and Nolin's links with British nurseries and gardens; see notably, https://crcv.revues.org/13374, accessed 30 August 2019.

15 'Ce n'est point un jardin anglais qu'on a voulu faire à Monceau, mais précisément ce qu'on en a dit en faisant la critique, réunir dans un seul tous les temps et tous les lieux. C'est une simple fantaisie, le désir d'avoir un Jardin extraordinaire, un pur amusement, et non le désir d'imiter une Nation qui, en faisant des Jardins naturels, passe le rouleau sur tous les gazons et gâte la nature en y montant partout l'art compassé du jardinier sans imagination...', Louis Carrogis, known as Carmontelle, Jardin de Monceau (Paris, 1779), preface.

16 'Brown \& d'autres excellents artistes jardiniers firent encore quelques pas dans la carrière du nouveau goût'. In Hirschfeld, C. C. L. (1783). Théorie de l'art des jardins (1779) (4th section, p. 9). Leipzig. For the English translation, see Parshall, L. B. (Ed. \& trans). (2001). Assorted observations on the new garden taste. In Theory of garden art (p. 339). Philadelphia: University of Pennsylvania Press.

17 Hirschfeld, C. C. L. (1783). Theory of garden art (p. 11).

${ }^{18}$ Vercruysse, J. \& Guy, B. (Eds.) (2004). Coup d'œil sur Beloei: Écrits sur les jardins et l'urbanisme (p. 524). Paris: Honoré Champion.

${ }^{19}$ Walpole, H. (1849). History of the modern taste in gardening [1771], Anecdotes of painting in England (Vol. III, chap. XXIII, p. 811), edited by Ralph Wornum. London: Henry G. Bohn. 
They say he has such an accurate and quick eye that after his one-hour ride, he could pen the design of a whole park, and after that, he only needed half a day to finish off the outline on the site. It is felt that one cannot trace an English garden on paper, it is the topography that decides it all, and the points of view indicate how to distribute the necessary masses. ${ }^{20}$

Marc de Bombelles' Journal contains eight references to Brown unambiguously presented as 'celebrated' and 'famous': the French visitor realised that 'what the French call jardin anglais had nothing to do with the Brownian model and only exhibited a cheap kind of Picturesque, in a straightened frame; Bombelles saw that Brown worked on a different scale from the French, and remarked that apart from Ermenonville, the jardin anglais could not be compared with Brown's designs. ${ }^{21}$ Several insights may be gained from Malesherbes' Voyage, written in 1785 - yet again a private account of Brown's legacy: he referred to Brown in relation to Nuneham Courtenay, to his genius for Blenheim and to his being 'the famous Brown' at Bowood, although not always feeling positive about him: 'His park has been much worked upon by the celebrated Brown, at a huge cost especially in earth moving, but the success is mediocre. In the lowest part lies a pool which has taken the shape of a beautiful and large river, its well-shaped contours hiding its beginning and end'.2 Malesherbes also commented on Ingress Park, Chatsworth, Prior Park, Longleat, Sherborne Castle, and Broadlands House but without ever mentioning Brown explicitly. A confirmation of the gradual acceptance of the name of Brown comes with Lady Craven's remark in 1789, when she noted that in France everyone thought Brown to be French: 'Sir George must not be too highly flattered at this, for the French are so fond of monopolizing all that is worth possessing, that Prince Eugene and our Capability Brown, with many others, are claimed by them.23 Lady Craven rightly perceived the French habit which consists in assuming any remarkable artist or thinker to be necessarily French.

Brown's appearance in The English Garden (1780) was very brief since William Mason sent him out of the poem to a distant future when a prose writer might wax lyrical about him: 'Bards yet unborn, shall pay to Brown that tribute, fittiest paid in strains, the beauty of his scenes inspire'. It was the French translator who granted him a greater share of the page in a footnote of Le Jardin anglais (1788):

M. Brown deceased lately, is the one who has carried this art to its grandest perfection for taste and intelligence. In England it is very rare that the gardener of the house should also be the one who designs and plants the garden, he is only destined to tend to and care for it. ${ }^{24}$

Thus, at the end of the day, the eighteenth-century reception was limited and often indirect. The French did not dislike Brown: they simply had not heard much about him despite many options available to them discovering him during trips to England between the end of the Seven Years War and the French Revolution troubles. What remains to be elucidated is why Brown went so unnoticed between 1763 and his death; suggestions are made towards the end of the chapter that will shed some light on resolving this mystery.

\footnotetext{
${ }^{20}$ de La Rochefoucauld, F. A. F. (1945). Mélanges sur l'Angleterre (1784) (p. 78). Paris, G. le Prat: 'On dit qu'il avait le coup d'œil si sûr et si prompt, qu'après une heure de promenade à cheval, il concevait le dessin de tout un parc, et qu'après cela, une demi-journée suffisait pour le tracer sur le terrain. On doit sentir qu'il est impossible de tracer un jardin anglais sur du papier, le pays où il est placé décide de tout, et les points de vue indiquent les masses nécessaires pour les faire répartir'. For the English edition, see A Frenchman in England, 1784, being the Mélanges sur l'Angleterre of F. de la Rochefoucauld. Newly edited from the MS with an introduction by Jean Marchand (Cambridge: Cambridge University Press, 1933).

${ }^{21}$ Marc de Bombelles, Journal de voyage en Grande-Bretagne et en Irlande (1784), reprinted by Jacques Gury in Journal (Oxford: The Voltaire Foundation, 1989) and Le Voyage Outre-Manche. Anthologie de voyageurs français de Voltaire à Mac Orlan, $18^{\mathrm{e}}$ au $20^{\mathrm{R}}$ siècles (Paris, Laffont, 1999).

22 De Lamoignon de Malesherbes, C.-G. (2009). Voyage en Angleterre (p. 172), edited by M. Crogiez Labarthe. Paris: Éditions Desjonquères: 'Son parc a été fort travaillé par le fameux Brown, avec une dépense très considérable surtout en mouvement de terrain, mais le succès a été médiocre. Dans la partie la plus basse est un étang qui a pris la forme d'une belle et large rivière, dont les contours heureux cachent la naissance et la fin'.

23 Craven, Lady E. (1789). A journey through the Crimea to Constantinople: In a series of letters (p. 16). London.

${ }^{24}$ Masson, M. (1788). Le jardin anglais.
} 


\section{Nineteenth-Century Reception}

Although silent in its first edition of 1776, Jean-Marie Morel's Théorie des jardins ou l'art des jardins de la nature contained important references in its second edition published in 1802. He was much taken with Brown, and described in detail the flooding of the valley at Blenheim and the metamorphosis of a ludicrously gigantic, but waterless, bridge into a powerful, well-proportioned bridge spanning a beautiful lake - his 'master-stroke', to use Walpole's term about Kent's brainchild. Morel went on to argue that Brown 'tempered his art', meaning that he was subtle in his use of architecture:

What proves yet again that Brown reasoned his art is that he did not let himself be overcome with 'templomania, with which the English overburden their gardens. Although an architect himself, despite the inviting size of the park at Blenheim, he confined himself to the cascade and to a stone bridge placed at the very end of the river. ${ }^{25}$

Morel did not go as far as to portray Brown as an inspiration or mentor but he acknowledged there was great elective affinity between them. An estate where he may be said to have distilled a Brownian touch is Guiscard, near Compiègne (Figure 13.4). Morel presented Brown's park-making and management at Blenheim as an endorsement of his own theory, thus arguing that Brown's art proved the relevance of his own theory of dividing designed landscapes into four distinct genres (expounded in Chapter two of his Théorie) - the 'land' (or 'pays' in French), the 'park', the 'garden proper', and the 'farm':

Note. That this judicious artist adopted the genre of the 'park' for his composition of the gardens at Blenheim corroborates my motivations for devising a division into genres which can be read further in chapter 2 of this book.

He called Brown 'one of the best artists England has ever produced'. A careful contextual reading of his praise highlights that, in French minds, Brown was immediately perceived as an agent of nature: 'Blenheim, planted in a formal way, has been recomposed since and given back to nature by Brown, one of the best artists England has produced'.6 While this may come across as a compliment, the rhetoric of a Brownian 'return to nature' was progressively understood by subsequent authors in a negative sense as a denial of art and an impoverishment. Brown's signature was self-effacing, and therefore may simply not have been recognised as a significant 'hallmark' or identifiable style abroad.

The second extensive reference to Brown is dated 1803 from Jean-Louis Ferry de Saint-Constant (17551830). Interestingly enough, it is not in the hands of a practitioner or theorist but those of a traveller with an interest in gardening and natural history. Indeed, Ferry de Saint-Constant, born in Italy and author of a book on Buffon, devoted a whole chapter to gardens and another one to gardeners in his London and Englishmen (Londres et les anglais, 1803). Blenheim is presented as the 'best laid-out garden in England' and recognised as a Brown landmark ('construit par le célèbre Brown'). ${ }^{27}$ Ferry de Saint-Constant had read Morel and relied on his description of Blenheim: 'As a whole, it unites grandeur and nobility to an elegant simplicity, the character pertaining to a park, the only garden that could be found on the site, and which befitted the importance of the palace and the dignity of the nation whose gift it was. ${ }^{28}$ But, immediately after quoting Morel, Ferry de SaintConstant adopted a critical stance and added: 'A park is not a landscape; thus Blenheim, despite its beauty,

${ }^{25}$ Morel, J.-M. (1806). Théorie des jardins ou l'art des jardins de la nature (Vol. 1, preface, p. cciv). Paris: 'Ce qui prouve encore, que Brown raisonnait son art, c'est qu'il ne s'est pas laissé subjuguer par la manie des fabriques, dont les anglais surchargent leurs jardins. Quoiqu'architecte lui-même, quoiqu'invité par la grande étendue du parc de Blenheim, il s'en est tenu à la cascade et à un pont en pierre, placé à l'extrémité de la rivière'.

${ }^{26}$ Morel, J.-M. (1806). Théorie des jardins (preface, p. cxxj): ‘Blenheim, magnifique château et vaste parc, fut donné par la nation au fameux duc de Marlborough, en reconnaissance de ses services. Le jardin, planté régulièrement a été recomposé depuis et rendu à la Nature par Brown, un des meilleurs artistes qu'ait produit l'Angleterre'.

${ }^{27}$ Ferry de St-Constans, J. L. (1803). Londres et les Anglais (Vol. 3, p. 189). Paris.

${ }^{28}$ Ferry de St-Constans, J. L. (1803). Londres et les Anglais (Vol. 3, p. 200): 'Ce jardin, un des mieux traités, réunit dans son ensemble, la grandeur et la noblesse à une élégante simplicité: caractère qui constitue le Parc, seul genre de jardin que comportait le site, qui convenait à l'importance du château et à la dignité de la nation qui en a fait le don'. 


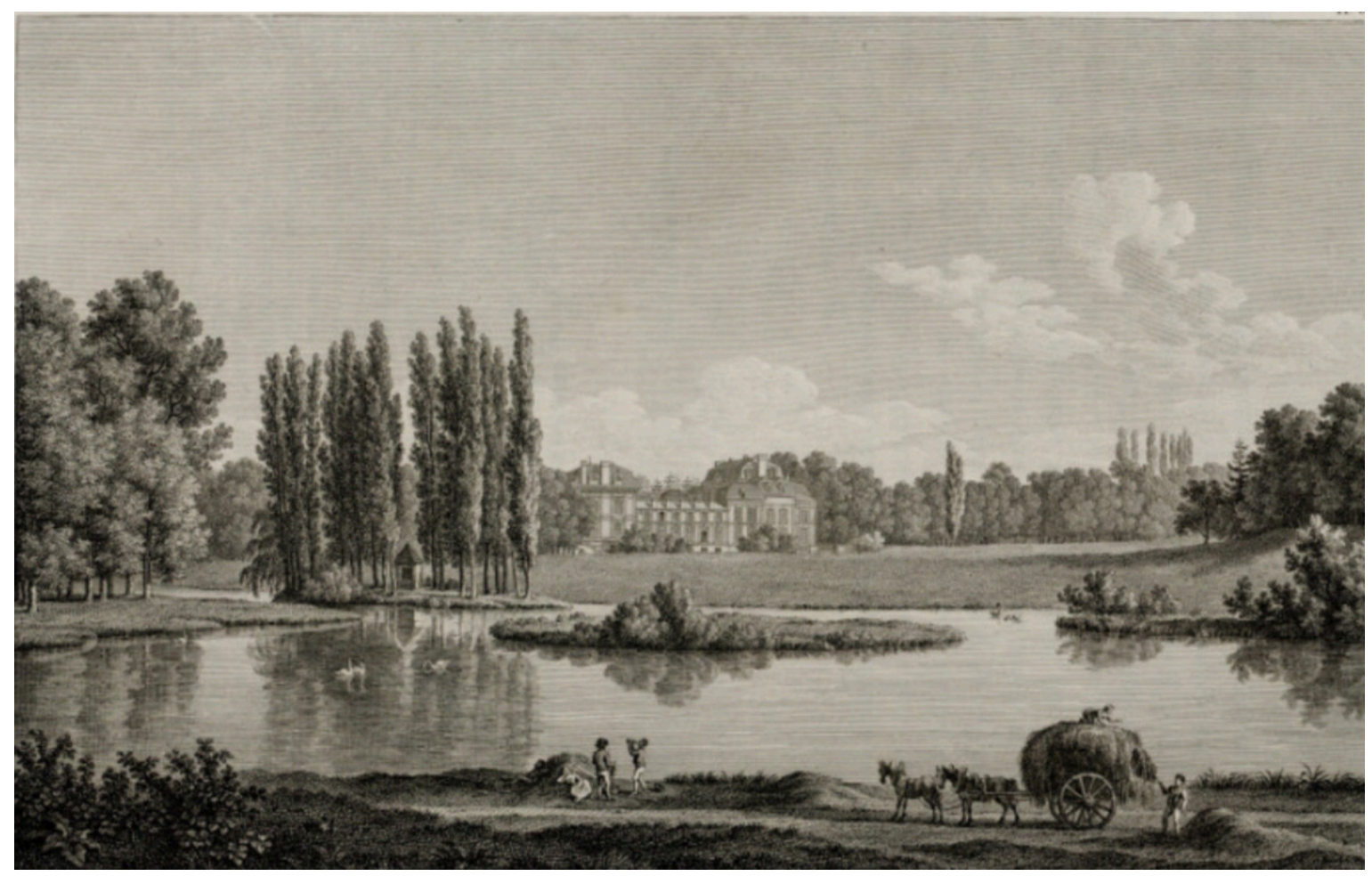

Figure 13.4: Le château de Guiscard, Constans Bourgeois, in Description des nouveaux jardins de la France, Alexandre de Laborde, 1808. Photo copyright Laurent Châtel, CC BY-NC 4.0.

has a sad and darkened character, a trait common to almost all gardens in England. ${ }^{29}$ In fact, Ferry de Saint-Constans was very critical of the notion that garden art should be an art of 'landscape making' and at every turn he took issue with the idea of the garden as an 'artificial landscape', claiming that English gardens never could rival nature and natural 'landscapes': 'Brown's gardens per se are in general well done; but his landscapes, i.e, what constitutes the new genre, are monotonous and sad, and they exhibit everywhere the efforts of art. $^{30}$

After criticising Kent, he deplored that Brown, who 'dared walk away from the beaten track and create new rules for himself', did not live up to expectations of his being 'the legislator of garden art' as had been anticipated at first:

People are now beginning to recognize that, as a landscape gardener, he does not deserve the reputation he has had and that his theory is wrong on several fundamental points. Brown trained as a gardener only. He lacked imagination, and a painter's eye, and formed his style, or rather his design, on the model of a parterre. ${ }^{31}$

\footnotetext{
${ }^{29}$ Ferry de St-Constans, J. L. (1803). Londres et les Anglais (Vol. 3, p. 189): 'Un parc n'est pas un paysage; aussi Blenheim, malgré sa beauté, a-t-il un caractère triste et rembruni, défaut essentiel commun à presque tous les jardins d'Angleterre'.

${ }^{30}$ Ferry de St-Constans, J. L. (1803). Londres et les Anglais (Vol. 3, p. 200): 'Les jardins, proprement dits de Brown, sont en général bien faits; mais ses paysages, c'est-à-dire, ce qui constitue le nouveau genre, sont monotones, tristes, et laissent voir partout les efforts de l'art'.

${ }^{31}$ Ferry de St-Constans, J. L. (1803). Londres et les Anglais (Vol. 3, p. 200): 'On commence cependant à reconnaître qu'il ne mérite pas comme jardinier-paysagiste, la réputation dont il jouit, et que sa théorie est fausse dans plusieurs points fondamentaux. Brown n'avait fait que les études d'un jardinier. N'ayant ni l'imagination, ni l'oeil d'un peintre, il forma son style, ou plutôt son plan, sur le modèle d'un parterre'.
} 
Relying on Uvedale Price for his descriptions and analysis throughout, he quoted long extracts from the Essay on the Picturesque - an indication that he was well versed in the more recent literature and was an early historiographer of gardens:

Presumption was this artist's principal trait; he was so well-known for his arrogance that he was nicknamed 'Brown the capable' (capability Brown). One day when one of his works was being praised, he exclaimed, 'only Brown and the God of this universe can do such things!'32

It is interesting that in apprehending Brown the French misunderstood what 'capability' meant (a talented man as opposed to topographically wise) and designated Brown, literally speaking, with a lower-case 'c' (capability Brown), not a capital 'C'.

We have here an interesting case of a secondary or 'second-hand' reception. It is perhaps significant that during this later stage in post-revolutionary France, Brown was perceived by the French not just through personal visits to England, which had become almost impossible between 1793 and 1802, but also through the indirect lens of English authors and critics of Brown, such as Price and Knight, who passed on a retrospective, negative appraisal of Brown. At that stage the knowledge the French gained of Brown was second-hand, filtered information, processed by a generation of British amateurs who examined Brown with hindsight and with a critical eye. Ferry de Saint-Constant had not just been content with reading Morel's newly augmented and updated edition, which on the whole painted a largely positive picture, but had discovered adversaries of those he termed 'the Brownists':

The pitfall in which M. Repton and all the Brownists fall is that they follow patterns. They become manierists, either because they grow fond of what they have already achieved, or because it is easy to carry on with what has often been practised..$^{33}$

Whilst Duchesne had, in 1775, supplemented individual travel and word of mouth with bookish knowledge, by the 1790s we have a very early instance of scholarly knowledge and secondary sources supplementing a 1790 s visit to England. It is fascinating to see that as early as 1803 Ferry de Saint-Constans could theorise and systematise Brown into a school or genre ('les Brownistes'); clearly he was aware that there were systematic, formulaic patterns in Brown's designs and that he had attracted followers. He was extremely thorough and clear-sighted in his close reading of sources since he was able to adjudicate between varying judgements: he thus conceded that Knight and Price 'may have overexaggerated Brown's defects' but felt that undeniably 'their principles tend to make gardens more varied and pleasant. ${ }^{34}$ With Ferry de Saint-Constans's reception, one holds an important key: Knight and Price annihilated the limited reputation Brown had gained up until then; the indirect impact of the Picturesque authors may have swept Brown under the carpet since he was only mentioned in relation to the criticism levied against him in Britain. A few years later, however, in his Description des nouveaux jardins de la France, Alexandre de Laborde portrayed Brown favourably, hinting at his simplicity. Brown had jocularly 'said about the serpentine paths which several individuals made in their gardens, that one could place a foot in zig and another in zag. ${ }^{35}$ And yet Amédée Pichot's account in 1825 disparaged Brown for being 'mannerist':

${ }^{32}$ Ferry de St-Constans, J. L. (1803). Londres et les Anglais (Vol. 2, p. 203): 'La présomption était le caractère principal de cet artiste; il était si connu sous ce rapport qu'on l'appelait Brown le capable (capability Brown). Un jour qu'on louait devant lui un de ses ouvrages, 'il n'y a, dit-il, que Brown et le Dieu de l'univers qui puissent faire de pareilles choses!'.

${ }_{33}$ Ferry de St-Constans, J. L. (1803). Londres et les Anglais (Vol. 2, p. 202): 'L'écueil contre lequel échouent M. Repton et tous les Brownistes, c'est de suivre un système. Ils deviennent maniéristes, soit parce qu'ils sont attachés à ce qu'ils ont déjà fait, soit parce qu'il est aisé de faire ce qu'on a souvent pratiqué'.

34 'M. Knight a soutenu les mêmes opinions dans un poème intitulé Le Paysage, accompagné de notes critiques. Tous les deux ont montré beaucoup de talent, de goût et de connaissances; peut-être ont-ils exagéré les défauts de Brown, mais il est incontestable que leurs principes tendent à rendre les jardins plus variés, plus agréables. M. Repton a fait l'apologie de Brown dans une lettre qu'il a adressée à M. Price, et dans son grand ouvrage, dont il a paru depuis peu une magnifique édition. M. Marshall, célèbre agronome, a aussi pris la défense des Brownistes, dans l'Examen critique des ouvrages de MM. Price et Knight': Ferry de St-Constans, J. L. (1803). Londres et les Anglais (Vol. 2, p. 206).

35 de Laborde, A. (1808). Description des nouveaux jardins de la France et de ses anciens château (p. 211). Paris: 'Brown disait plaisamment, des chemins tournants que plusieurs individus faisaient dans leurs jardins qu'on pouvait mettre un pied en zig et l'autre en zag'. 
Brown completed several of Kent's designs and, in some villas, made some changes to his ideas with happy results; but being a bit mannerist, Brown carried the hatred of the straight line a stage further than Kent; hence he multiplied a bit too often the zig-zags and labyrinths. The theory of the English garden was explained by Repton with great talent in treatises ex-professo, of which I have only read the report made in the Quarterly Review. I will retain from this work a sense of anxiety about the future of parks and gardens, which might benefit our landowners. ${ }^{36}$

This critical approach is echoed by Joseph-Alexis Walsh de Serrant, a French traveller who, despite his enjoyment of Blenheim, an absolute 'must' for French visitors to England, pointed to the social status of Brown and the all-too easy professional aspirations of gardeners:

This one Mr Brown, now famous across England, was once a garden boy; often his masters would scold him, often he would stop what he was doing, and, leaning on the arm of his spade or rake, he was contemplating the countryside, and then drawing lines in the sand which he was the only one to grasp. It was then that he refined over his art: his poetical eye would embrace the country, his young imagination created landscapes, raised hills and made rivers serpentine. ... It is regrettable that Brown was a gardener; for today any man employed in any garden who has held a spade or a rake in his kitchen garden, has thought it apt to leave his sphere and following Brown's example, take up the role of landscape architect. ${ }^{37}$

After Jean-Marie Morel, the next outstanding figure who praised Lancelot Brown is Narcisse Vergnaud (17941848) in his L'art de créer les jardins (1835); his account of Brown owed a lot to his admiration of Blenheim, for which he produced three plates, including one beautiful coloured which undoubtedly would have influenced generations of later landscape architects (Figure 13.5). Blenheim had long been a key stage along the French tour of English gardens, but Vergnaud's enthusiasm in 1835 was a very striking and warm tribute:

It seems indeed that such an amount of straight lines all confined to one spot was meant to highlight, in Brown's masterpiece, the genuine grandeur which results from having within a garden a happy use of natural curbs harmoniously echoing the shape of the terrain and the general character of the site. Brown had enough genius to understand how a vast palace with its heavy masses flanked by turrets, and conveniently placed at the heart of a park of three thousand acres planted with already mature trees, could reach the maximum effect: he sketched at one go the principal picture and all the accidental views he could conjure up with such an architectural mass, designing the middle ground within the various topographical accidents and in the groupings of the most beautiful trees. ${ }^{38}$

${ }^{36}$ Pichot, A. (1825). Voyage historique et littéraire en Angleterre et en Écosse (3 Vols). Paris: 'Brown continua plusieurs plans de Kent et modifia avec bonheur ses idées dans certaines villas; mais un peu maniériste, Brown a poussé plus loin que Kent la haine de la ligne droite; aussi multipliait-il peut-être trop les zig-zags et les labyrinthes. La théorie du jardin anglais a été expliquée avec talent par M. Repton dans des traites ex-professo, dont je n'ai lu, je l'avoue, que l'analyse dans le Quarterly Review. J'emprunterai à cet ouvrage l'expression de quelques craintes sur l'avenir des parcs et des jardins anglais dont nos propriétaires pourront faire leur profit'.

37 Joseph-Alexis Walsh de Serrant, Lettres sur l'Angleterre, ou voyage en Grande-Bretagne en 1829, (Paris, 1830); quoted in Gury, J. (1999). Le voyage Outre-Manche (p. 504-505). Paris: Laffont: op.cit. 'Brown, devenu fameux en Angleterre, avait été garçon jardinier; souvent ses maîtres le grondaient, souvent il suspendait tout à coup son ouvrage; et, s'appuyant sur le manche de sa pelle ou de son râteau, on le voyait regarder les campagnes, et puis dessiner sur le sable des traits que lui seul comprenait. C'était alors qu'il étudiait son art: son œil poétique s'emparait du pays, sa jeune imagination créait des paysages, élevait des collines et faisait serpenter des rivières. ... Il est fâcheux que Brown ait été jardinier; car aujourd'hui tout homme qui est attaché à quelque jardin, qui a tenu la pelle ou le râteau dans un potager, s'est cru en droit de quitter sa sphère, et, à l'exemple de Brown, de s'élancer dans le genre paysagiste'.

${ }^{38}$ Vergnaud, N. (1835). L'art de créer les jardins: contenant les préceptes généraux de cet art; leur application développée sur des vues perspectives, coupes et élévations, par des exemples choisis dans les jardins les plus célèbres de France et d'Angleterre; et le tracé pratique de toute espèce de jardins (p. 71). Paris: 'Il semble, en effet, que cet amas de lignes droites soit resté là, dans un coin, pour mieux faire apprécier, dans le chef-d'œuvre de Brown, la grandeur véritable qui résulte toujours, pour un jardin, de l'heureux emploi des courbes naturelles en harmonie avec la conformation du terrain et le caractère général du site. Brown eut assez de génie pour comprendre tout l'effet d'un vaste palais avec ses massifs flanqués de tourelles, convenablement situé au milieu d'un parc de trois mille arpens plantés d'arbres déjà fort anciens: il esquissa d'un seul trait d'ensemble le tableau principal et toutes les vues accidentelles qu'il pouvait produire avec une telle masse de construction, en ménageant les plans intermédiaires dans les divers accidents de terrain et dans les groupes des plus beaux arbres'. 


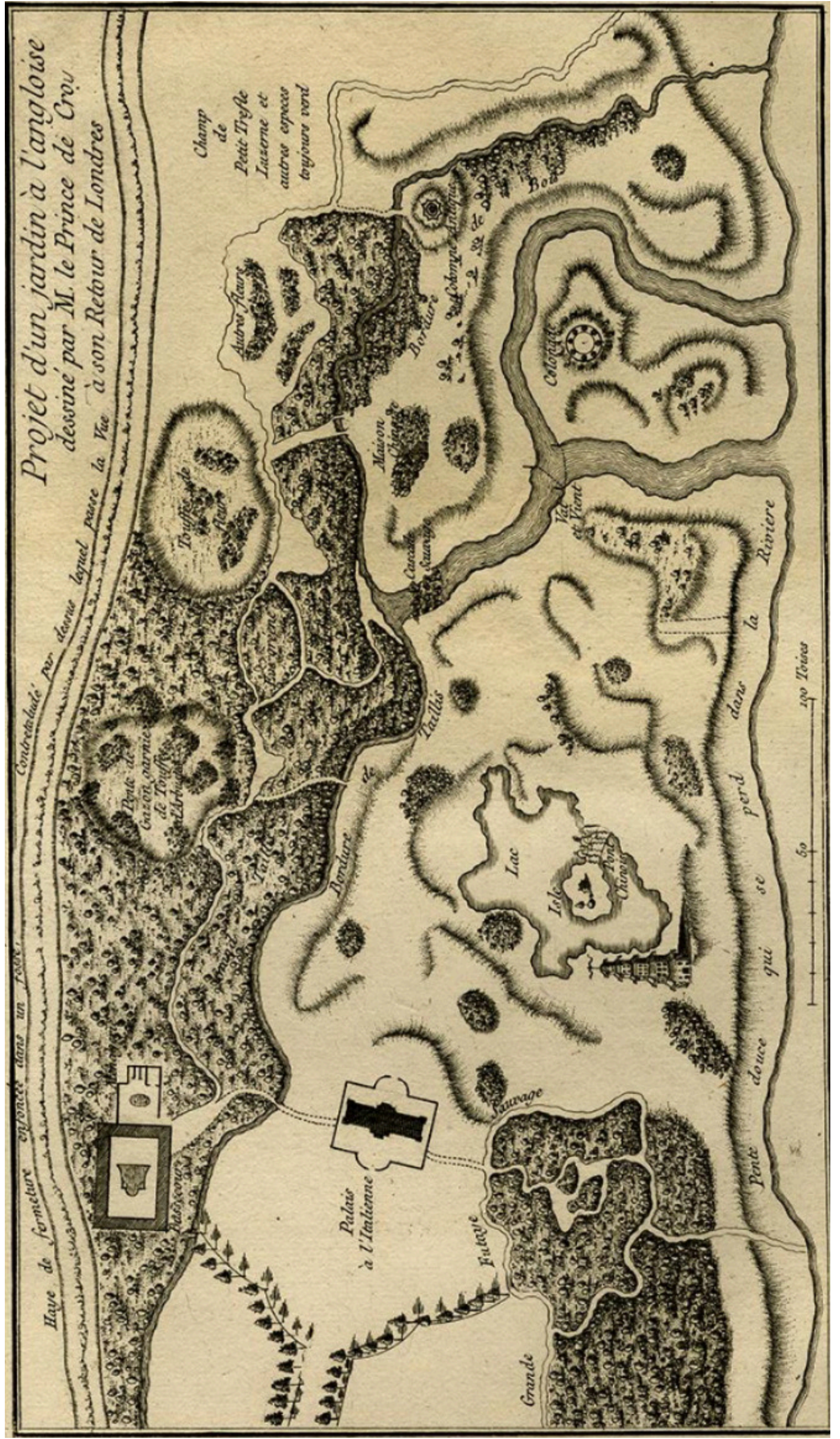

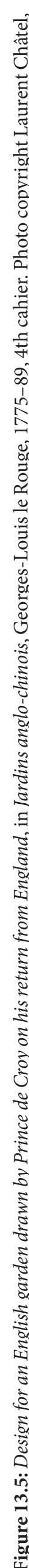


Curiously, as a landscape designer, he thought of Blenheim only in visual terms, pointing to the Picturesque 'capability' or 'potential' of the site, its capacity to raise pictures: he stated that up on the hills were new tableaux worth Claude's brush as well as 'accidental vistas'. It is as if his appreciation of Brown was shaped by mid-eighteenth-century expectations and a 'Picturesque' frame of mind, with no reference to other senses or perceptions of the place. Vergnaud concluded his description of Blenheim on the 'immortal genius of Brown', who shied away from adding 'a crowd of details then still fashionable', hinting here at the French lassitude with 'fabriques' all squeezed together.

On the strength of Morel and Vergnaud, the great French garden historian Arthur Mangin conveyed an equally enthusiastic French perception of Brown, both in Les jardins: histoire et description (1867) and Histoire des jardins anciens et modernes (1887). Similarly, Edouard André also took inspiration from Vergnaud and reiterated the fascination for Blenheim in L'Art des jardins: Traité général de la composition des parcs et jardins (1879); it is clear in Edouard Andrés mind that Brown owed his success to Blenheim:

He then went to Blenheim, threw a dam across the valley, and made a huge lake in eight days, and acquired for himself all of a sudden a huge popularity. Everybody wanted his advice; he became the idol of the day and made a fortune rapidly. ${ }^{39}$

However, Edouard André adopted a more critical outlook under the influence of John Claudius Loudon, whom he read closely; not only was Loudon translated into French ${ }^{40}$ but Edouard André, being an Anglophile travelling and working in England, would have been very familiar with Loudon's An Encyclopaedia of Gardening and the Gardener's Magazine, which he used extensively as a direct source for his treatise. As an illustration of the way passages were directly lifted from Loudon's Encyclopaedia and adapted for Andrés purposes, here are two extracts put side-by-side:

[Edouard André:] However, one may address serious criticisms to Brown. He is the one who invented plantations as a belt, that is a continuous tree mass which encircled the property, thus forming an interior landscape without letting in outside scenery. Moreover, he has been accused of imagining groups of isolated trees along circular lines in the plains. He called them clumps. These clumps are the plague of landscape parks wherever they are to be seen, planted by people who have taken to this pitiful system. Furthermore, Brown always conferred equal contours to his lakes; you could spot his style in a thousand, and the forms he used were stereotyped, just as his compact plantations in sinuous lines were almost regular, revealing only too clearly the gardener and not enough the artist. In a nutshell, one could feel Brown's roots, inferior to one like Kent or Shenstone, who designed a park as one would paint a landscape on canvas, always more concerned with effect rather than details, with being picturesque rather than pretty and mannered. ${ }^{41}$

[J.C. Loudon:] That Brown must have possessed considerable talents, the extent of his reputation abundantly proves but that he was imbued with much of that taste for picturesque beauty which distinguished the works of Kent, Hamilton, and Shenstone, we think will hardly be asserted by anyone who has observed attentively such places as are known to be his creations. Whatever be the extent or character of the surface, they are all surrounded by a narrow belt, and the space within is distinguished by numbers of round or oval clumps, and a reach or two of a tame river, generally on different levels. ${ }^{42}$

This juxtaposition highlights in an illuminating way how André imbibed and interpreted Loudon, thus generating what we might refer to as 'cultural transfer'; it illustrates the way ideas percolated and were translated

${ }^{39}$ André, E. (1879). L'Art des jardins. Paris: Masson: 'Il vint ensuite à Blenheim, jeta une digue au travers d'une vallée, fit ainsi une lac immense en huit jours et s'acquit, tout d'un coup, une immense popularité. Tout le monde voulut recevoir ses conseils; il devint l'idole du jour et fit une fortune rapide'. This is in fact a translation of Loudon's Encyclopaedia, Part 1, p. 250.

${ }^{40}$ Loudon, J. C. (1830). Traité de la composition et de l'exécution des jardins d'ornement, traduit par J. M. Chopin, edited and annotated by M. le chevalier Soulange-Bodin. Paris.

${ }^{41}$ André, E. (1879). L'Art des jardins (p. 75). Paris: Masson: 'Cependant on peut adresser à Brown de graves reproches. C'est lui qui inventa la plantation en ceinture, c'est-à-dire le massif d'arbres continu dans lequel il enserrait toute propriété, ne formant ainsi qu'un paysage intérieur sans y faire entrer les scènes d'alentour'.

${ }^{42}$ Loudon, J. C. (1850). An encyclopaedia of gardening (2nd ed.), edited by Mrs Loudon (Part I, chap. 4, p. 250). London: Longman, Brown, Green, and Longmans. 
from England over to France. After 1900, a resurgence of the so-called 'style à la française' swept Brown under new parterres, until British historiography, in the 1950s, with Dorothy Stroud notably, took Brown and raised his reputation up to the standing it maintained in twentieth-century minds and prose. ${ }^{43}$

\section{An Excessive Focus on Brown? A Need for a Larger Picture}

The discrepancy between British high expectations about Brown and the arguably limited French reception can be accounted for by what may be called a British entrenched national garden historiography, which has placed Brown on a high pedestal over the years despite contrary evidence of a more qualified picture of Brown's place in English garden history between 1784 and 1950. Recent British studies have also contributed to a reassessment of Brown's exact achievements. ${ }^{44}$ I have argued elsewhere about the benefits of reception in garden history as a 'corrective' or safeguard against unduly hagiographical accounts; here is the perfect opportunity, through Brown's case, to see how French reception corrects the excessive focus on Brown and provides a remapping of British historiography. ${ }^{45}$

The French perception of garden creativity in Britain certainly did not champion Brown as it was shaped early on by names and places before Brown's arrival. By the 1780s the French had plenty of evidence and material of what an English garden ought to be like and the name of Brown was not a major touchstone.

The first important French entry into English garden creativity can clearly be said to be Thomas Whately's seminal Observations published in 1771 but one should not forget that the French had Girardin to rely on in 1777, which was also read in England using both the French original (as testified by William Burgh's commentaries on William Mason in 1782) and the English translation (in 1783 by Daniel Malthus). The 1770s clearly constituted a major turning point because seminal texts were published, causing a rise in the French awareness and understanding of gardens: William Chambers's publication of his Dissertation (1772), his exchanges with Voltaire and his trip to France in 1774; Watelet's Essai sur les jardins (1774); Girardin's De la composition des paysages (1777); and George-Louis le Rouge's plates in his widely circulated Jardins anglo-chinois (1776-89) (Figure 13.6). They all had a great impact on a wide French readership. In fact, by the 1790s the French had written their own history and account of what British creativity was all about. Monique Mosser has long argued that William Chambers was influential in crystallising the French reception. ${ }^{46}$ Indeed, Chambers was prominent throughout the second half of the eighteenth century, as the various reprints, uses, and misuses of his works testify.

The dissemination of Chambers's ideas gained extra strength through his bilingual Drawings of Buildings in 1757, Latapie's retranscription in 1771 of Chambers's text within the introduction to his translation of Whately, Le Rouge's 1776 pirated edition and forgery of Chambers (interpolating his own drawings and a fake garden design), Jacques Delille's reprint in 1782 in his footnotes to Les Saisons, the abbé Rozier's reprint in a 1785 'garden entry' in his Cours complet d'agriculture without even acknowledging Chambers's name, culminating with the wide-reaching distribution in 1772 of his Dissertation foregrounding the role of China. Both the French and the English fashioned a collective imaginary or cultural framework of 'natural gardening' based on artefacts and ideas related to China but the French were explicit in their acknowledgement of the role of China. The narrative of the genesis of Chinese-related ideas is well documented - although hardly ever accepted by British

43 Stroud, D. (1950). Capability Brown.

${ }^{44}$ See notably Brown, D. \& Williamson, T. (2016). Lancelot Brown and the Capability Men: Landscape revolution in eighteenth-century England. London: Reaktion Books; Phibbs, J. (2016). Capability Brown: Designing English landscapes and gardens. New York: Rizzoli; and Phibbs, J. (2017). Place-Making: The art of Capability Brown, 1716-1783. Swindon: Historic England.

${ }^{45}$ Châtel, L. (2012). 'Getting a full picture': Pour une nouvelle histoire des 'jardins anglais' des Lumières: perspectives croisées entre conception et réception. In P. Dubois \& A. Tadié (Eds.), Esthétiques de la ville britannique, XVIIIe-XIXe siècles: Hommage à Jacques Carré. Paris: PUPS. Previous seminal studies were Hunt, J. D. (2004). The afterlife of the garden. London: Reaktion Books; and Calder, M. (Ed.) (2006). Experiencing the garden in the eighteenth century. Berne: Peter Lang.

${ }^{46}$ Mosser, M. (1997). La perfection du jardin anglo-chinois. In M. Constans (Ed.), Bagatelle dans ses jardins (pp. 135-166) and especially Mosser, M., Barrier, J. \& Che Bing Chiu (2004). Aux jardins de Cathay: L'imaginaire anglo-chinois. William Chambers. Besançon: Éditions de l'Imprimeur. 


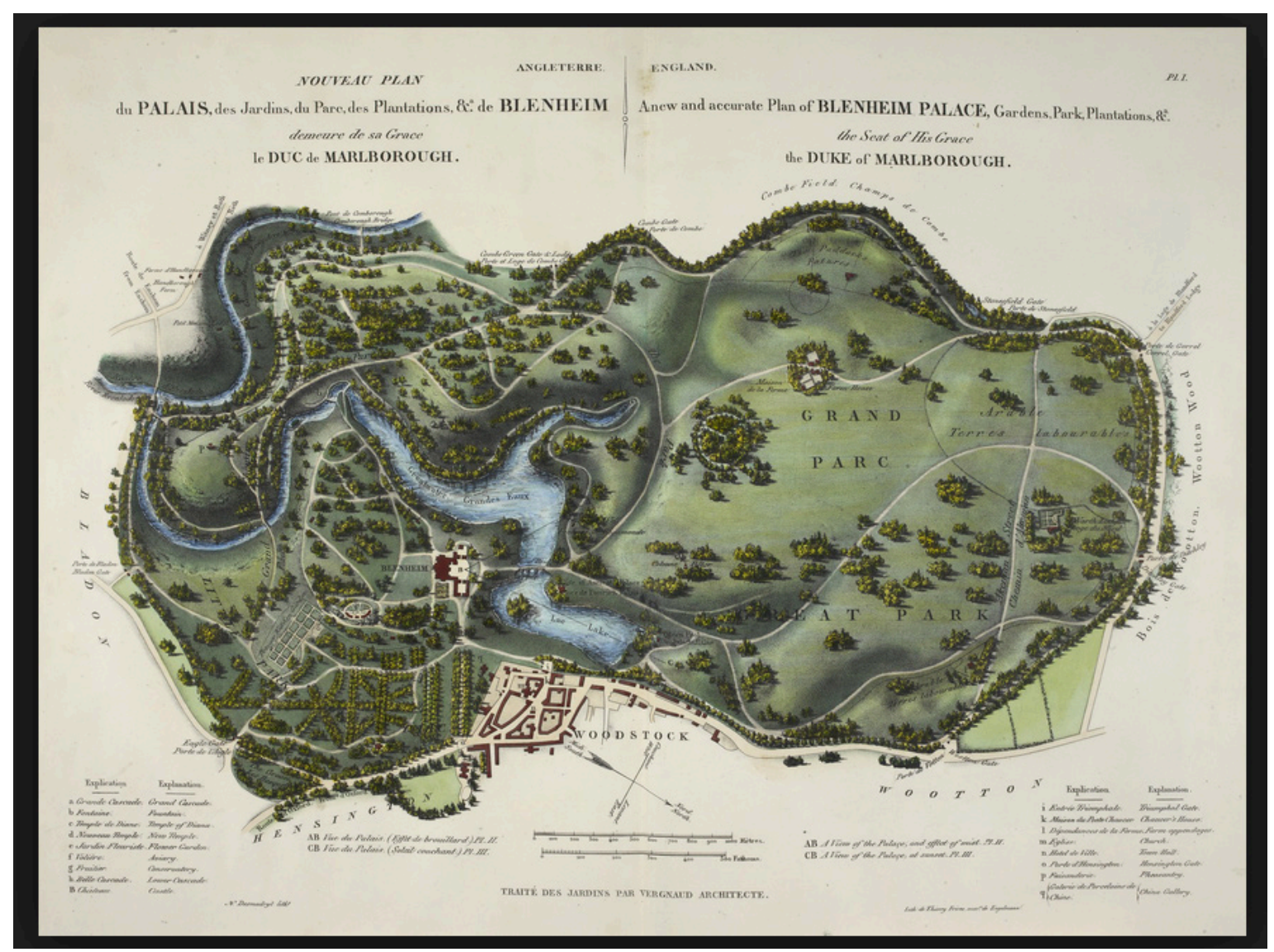

Figure 13.6: A New and Accurate Plan of Blenheim, in Traité des jardins, N. Vergnaud, 1835. Photo copyright Laurent Châtel, CC BY-NC 4.0.

historiography; ${ }^{47}$ the story often starts and ends in 1749 with Attiret's Lettres édifiantes et curieuses, and the controversy about who had access to Matteo Ripa's prints, while in fact the story ought to engage a much larger narrative of various other 'shocks of recognition' beyond just Attiret, triggered by descriptions, prints, cups, coffers, lacquer, and, above all, the decorative art items which displayed, for all to see, Chinese rocks, trees, and water arrangements in the very spirit of Whately's typology. As the English preferred Brown, the French relished the creative potential unleashed by evocations of China. Such bickering between the French and the English about the right way of naming or not naming the modern garden ('jardin anglais' or 'anglo-chinois') was ideologically motivated: a patriotic camp on the one hand with William Mason and Horace Walpole, defending an English 'invention' of gardening, was pitted against an international camp on the other hand with William Chambers, his French friends, and British aristocratic patrons, who defended a pan-European, cosmopolitan vision of 'modern gardening' - bickering, incidentally, translates in French as 'chinoiser', 'to bicker over something. ${ }^{48}$ With such a preference for Chambers in French minds, and Chambers being so critical of Brown, it is easy to see why Brown did not take pride of place in French garden historiography.

47 Siren, O. (1950). China and the gardens of Europe. New York: Ronald; Jacques, D. (1990). On the supposed Chineseness of the English landscape garden. Garden History, 18(2), 180-191; Yu Liu (2008). Seeds of a different Eden: Chinese gardening ideas and a new English. Columbia: South Carolina Press; Cheng, E. H. (2010). Britain's Chinese eye: Literature, empire, and aesthetics in nineteenthcentury Britain (Chap. 1). Stanford: Stanford University Press.

${ }^{48}$ For the argument about divided ideologies, see Châtel, L. (2006). Le jardin 'anglais': représentation, rhétorique et translation de la nation britannique, 1688-1820, art et nation en Grande-Bretagne au XVIIIe siècle. Revue Française de Civilisation Britannique, 13(4), 171-188; for the use of the term of 'modern gardening', see Châtel, L. (2013). Modern moral gardens, nature, National Trust, and 


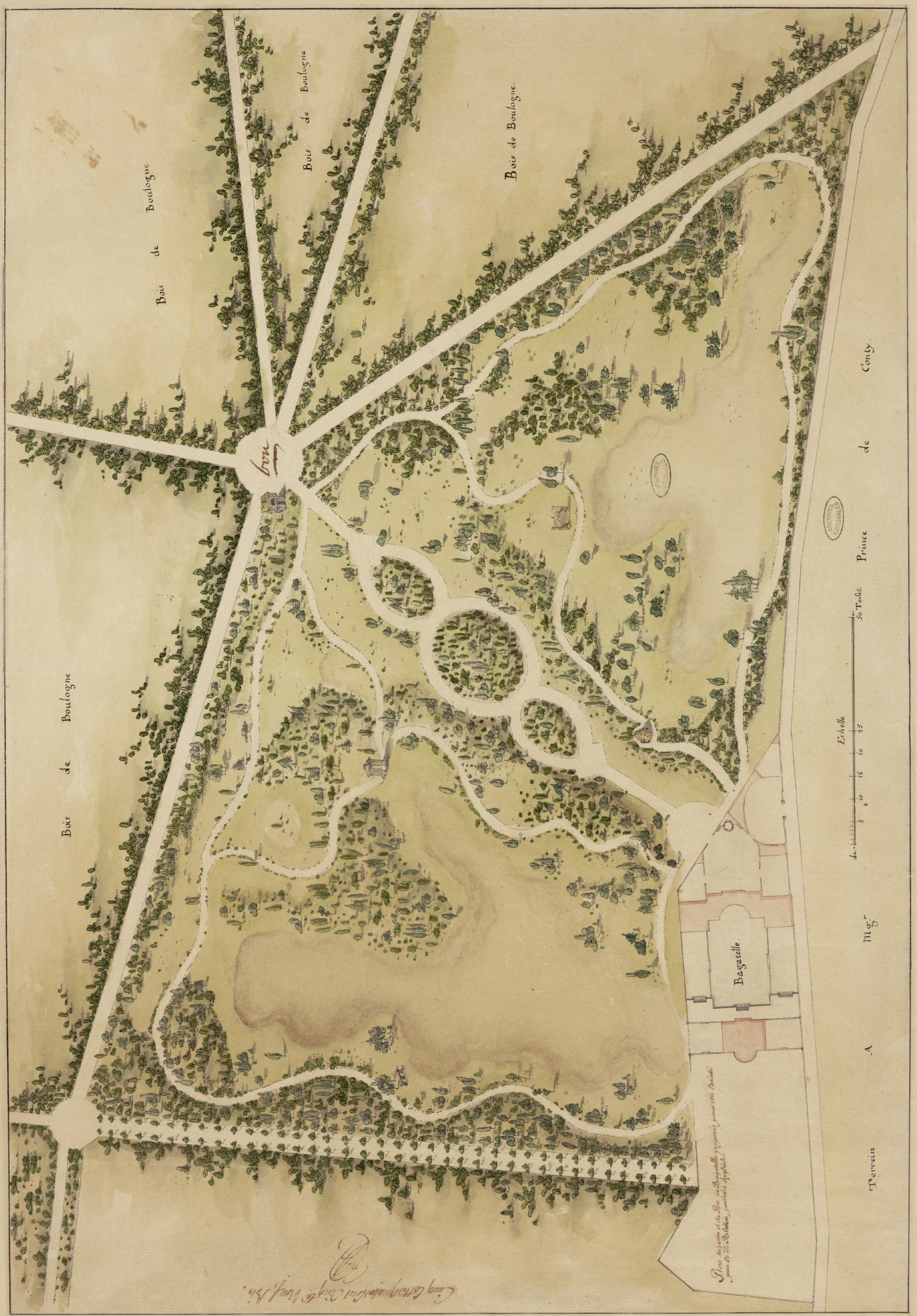


Moreover, one may also adduce another significant issue: size mattered. The impact of Brown in France may have been less important on account of the smaller size of properties in France, before and after the Revolution. This is attested by Duchesne's and Girardin's focus on the size of estates. In 1775, Duchesne clearly stated that new ideas and fashions, which he did not actually call 'English' but 'free', could not be implemented in France because it did not rank so many estates on a large scale:

Which piece of land suits free design. It would be too difficult to hide that the so-called freedom of nature is nothing but human work; a servile and disfigured copy, or even worse, the result of whim.... Is it not clear for all to see that in Europe, free gardens, so liked by the English, contain many thousands of acres? To be fully convinced one only has to cast an eye on the plan of Lord Cobham's garden at Stowe, the description of which helps give an exact idea of the free genre as much as excellent Whately's principles do. ${ }^{49}$

Finally, the export of Brown himself to France, as it were, was not so necessary as there were many Anglophile gardeners such as François-Joseph Bélanger and a whole diaspora of English and Scottish gardeners and designers who were the vital transmitters and conduits of 'modern gardening' with multiple exchanges and crossings of the Channel for the sake of plants and trees, notably Thomas Blaikie (1750-1838) (Figure 13.7). Recent studies on Blaikie point to his idiosyncratic absorption of British skills and ideas. ${ }^{50}$ The spirit of Brown may well have been translated on French soil here and there, but diluted and mixed up with highly personal, individual stylistic interpretations. Therefore, with or without explicit reference to Brown, Blaikie would have 'naturalised' estates in his own way, as can still be guessed at today, for instance, at Régnière-Ecluse in the Somme. ${ }^{51}$ These gardeners and garden enthusiasts could hardly be termed 'English' since, after a few years on the Continent, they had translated their ideas within national idioms and could be said to be as English as Italian or French - all making up, in fact, a pan-European garden creativity: a two-way cross-fertilisation that produced a modern style which it might be difficult to identify as being only English.

\section{Conclusion}

What the French reception highlights is that the reputation of Brown may not have translated across the channel. The English garden had some je ne sais quoi about it that allowed it to remain elusive enough, and subsume any number of practices, some good, some bad, some liked, some disliked, but without any one man's name standing out as the absolute champion. The signature of the designer mattered less than that of the landowner, especially in travellers' accounts, and it is twentieth-century historiography that has tended to produce a stylistic, teleological narrative with 'attributions', often crediting more Brown 'intent' than there ever was. It is more than likely that Kent had a more enduring impact on French taste for modern gardening than Brown; the actual 'discovery' of Brown coincided with an English denial of Brown in the hands of Chambers, Knight, and Price.

the modernity of eighteenth-century 'English' gardens. In B. Millet (Ed.), Modernitédu XVIIIe siècle - Hommage à Alain Bony, RSEAA XVII-XVIII (Hors-Série 3), 243-259.

${ }^{49}$ Duchêne, A.-N. (1775). Sur la formation des jardins (p. 85). Paris: 'A quel terrain convient la formation libre. Il y deviendroit trop difficile de dissimuler que cette prétendue liberté de la Nature, n'est qu'un ouvrage humain; une copie servile \& défigurée, ou pis encore, l'effet du caprice. ... Ne voyons-nous pas qu'en Europe, les Jardins libres, chéris des Anglois, contiennent plusieurs centaines d'arpens? Pour s'en convaincre, il suffit de jetter les yeux sur le Plan du jardin du Lord Cobham à Stoue, dont la description, sert autant que les excellens principes de M. Whateley [sic], à donner une vraie idée du Genre Libre?'

${ }^{50}$ See Barrier, J. \& Mosser, M. (Eds.) (2016). Journal d'un botaniste-jardinier (1775-1792): Un Écossais en France à la fin de l'Ancien Régime. Thomas Blaikie (1750-1838). Paris: Klincksieck. The index points to a number of English names mentioned by Blaikie.

51 See pictures available at http://www.parcsetjardins.fr/picardie/somme/parc_du_ch_teau_de_rEgniEre_ecluse-642.html, as well as https://regniereecluse.wordpress.com, both accessed 30 August 2019.

Figure 13.7 (page 196): Design for Bagatelle, Thomas Blaikie, 1777. Archives Nationales (France), General catalogue of maps, reference: N/III/Seine/586/1-N/III/Seine/586/9. Public domain. 
The French skipped over Brown, as it were, and their genealogy easily went from Bridgeman to Kent and onto Repton and Loudon.

Some might argue that the French were bound to condemn Brown to a much poorer reception than he truly deserved. Some might apply what Horace Walpole said about Richard Payne Knight, arguing that the French 'Jacobinically would level the purity of gardens' and 'would as malignantly as Tom Paine or Priestley guillotine Mr Brown. ${ }^{52}$ However, it is undeniable that, while Le Nôtre enjoyed and still enjoys an international reputation and standing, Brown emerges in French consciousness as one name amongst innumerable references to 'English' styles, names and practices.

\section{Select Bibliography}

A select bibliography is available at the end of this volume, or at: https://doi.org/10.22599/CapabilityBrown.o.

52 'Letter to William Mason, March 22 1796'; see Cunningham, P. (Ed.). (1859). The letters of H. Walpole (Vol. IX, p. 463). London: Richard Bentley. 